\title{
DISTRIBUTION AND ABUNDANCE OF PHYTOPLANKTON SPECIES IN BODNA RIVER IN KWALI, ABUJA
}

\author{
Sani Bilkisu Mohammed \\ Department of Zoology, Nasarawa State \\ University, keffi, Nigeria
}

\begin{abstract}
Abstract: Rivers are vital and vulnerable freshwater systems that are critical for the sustenance of all life. The Bodna River was analyzed for the abundance and distribution of phytoplankton species. The main aim of the study was to determine the presence of phytoplankton distribution and effects of human activities on the biological properties of the river, to further enhance conservation and management. Samples were collected insitu from the four sampling stations using plankton net of mesh size $50 \mu \mathrm{m}$. The water sample was concentrated to $100 \mathrm{ml}$ level into phytoplankton bottle, $1 \mathrm{ml}$ of Lugol solution was added and allowed to sediment for 24 hours. $91 \mathrm{ml}$ of the water sample decanted and left with $10 \mathrm{ml}$ of the sample used for species count with drop count method. Descriptive analysis of bar charts and Analysis of variance (ANOVA) were used to determine the percentage abundance of phytoplankton. The result showed 117379 phytoplankton species; four major families with 14 species of phytoplankton which include Chlorophyceae with species like Chlorella ellipsodea, Closterium species, Spirogyra species, Hormidium species and Ulothrix species; Bacillariophyceae with Melosira granulata, Fragillaria species, Nitzchria species, Diatomella species, Tabellaria species and Synedra species; Cyanophyceae with species such as Aphanocarpsa species, Oscillatoria species and Euglenophyceae with Phacus species. The most abundant species of phytoplankton from this study was Chlorella ellipsodea with total abundance of 26,556 and the least was Synedra species with a value of 1,970. There were variations within the sampling stations and within seasons. This study findings could be helpful to the community for sustainability of live food for the biological composition in the river.
\end{abstract}

Key words: phytoplankton, distribution, drop count, seasonal and River Bodna.

\author{
Banyigyi, A. H. and Makpo, J.D \\ Department of Zoology, Nasarawa State \\ University, keffi, Nigeria.
}

\section{INTRODUCTION}

Water is a unique liquid, it is essential for life and the most important medium through which living organisms can grow and flourish. Rivers are vital and vulnerable freshwater systems that are critical for the sustenance of all life, providing main water resources for domestic, industrial and agricultural purposes (Farah et al., 2002). Unfortunately, river waters are being polluted by indiscriminate disposal of sewage, industrial waste and a plethora of human activities that affect their physicochemical parameters and microbiological quality (Oboh et al., 2017, Efe, 2000). Aquatic ecosystem is a critical component of the global environment. In addition to being an essential contribution to biodiversity and ecological productivity, they also provide a variety of services for the human population such as irrigation, recreational opportunity and habitat for economically important fisheries (Dankishiya et al,, 2013).

Plankton is the basic food source for a variety of marine species, from tiny fish larvae such as cod all the way up to giant baleen whales. Phytoplankton are very important group of freshwater organisms. They occupy the primary trophic level as primary producers and food source for invertebrate and vertebrate groups in the aquatic environment. In nature, phytoplankton is fed on by zooplankton, which is equally fed on by other higher animals such as larger zooplankton, fin fish and shellfish. Almost all aquatic life depends on zooplankton at least at an early stage of their life. In nature, larvae of most fish and shellfish species eat small phytoplankton and zooplankton. Such a diet does not only provide a much-diversified composition, but has an auto digestion characteristic that facilitates nutrient uptake in the larvae.

Lovik and Kjellberg (2003) observed that trophic changes in lake environments could be highlighted through the study of the structure and composition of the planktonic communities, and the observation of the 
principal physical and chemical parameters of the waters. Such changes allow us to draw useful pictures about the state of water quality in the lake and on its trophic state. Studies by Boyd et al. (2000) have shown that the mineral element iron can cause increased blooms of many kinds of phytoplankton. Mizuno (1990) also theorized that large-scale "Seedling" of the world's oceans with iron would generate such massive blooms of phytoplankton to draw enough carbon dioxide to counteract the Greenhouse effect (or global warming). Direct exudation of dissolved organic carbon from phytoplankton is variable but often varies within 5 to $20 \%$ of the primary production, so when phytoplankton are growing carbohydrates activity are released in large amounts, and can contribute up to $70 \%$ of the Dissolved Organic Carbon (DOC) (Sondergaard et al., 2000). Levels of chlorophyll -a in phytoplankton are used to determine the level of primary production. However according to Jeffrey et al. (1997) a diverse range of pigments has evolved in the phytoplankton, conveniently providing important chemo taxonomic information concerning community composition and certain key pigments are signatures for various phytoplankton groups.

According to Pannard et al. 2007 depending on the season, phytoplankton responses differ in response to nutrient and light conditions, and to the intensity of stratification and mixing. Crul (1993), states that phytoplankton development in aquatic ecosystems is greatly enhanced by increased level of the major plant nutrients. This is because some of the nutrients are involved in the intercellular metabolic regulation and as building blocks in protein molecules. Both zooplankton and phytoplankton not only play a vital role in the stability of the marine ecosystem, but they also serve as an indicator of water health, since they are affected by slight changes in the environment (Barlow et al., 2006).

\section{MATERIALS AND METHOD}

Study Area

In Kwali region of FCT Nigeria, the problem is getting portable water because of environmental pollution and degradation. Bodna River in kwali area council of FCT, is a tributary to lower Usman dam. The river has a tremendous economic importance to the indigenous settlers which ranges from domestic usage, irrigation for agricultural activities and fishing. These activities are source of employment opportunities to some of the community members. However, less attention has been given to the Bodna River despite its importance in the lives of the inhabitants of the area, who rely mainly on the river for drinking, domestic water supply, fishing, farming, bathing, laundry and sand mining. The river is being polluted by the human activities such as; bathing, washing, refuse dumping and defeacation around the river banks. These activities in one way or the other affects the physicochemical parameters of the water body. Four sampling stations were used for this research.

Station 1 (Tukurwa): The River flows from the same source with a distance $10 \mathrm{~km}$ from the source. This area is surrounded sparsely by houses; fishing and irrigation farming is the predominant activity. The station coordinates are: Latitude $8^{0} 50^{1} \mathrm{~N}$, longitude $7^{0}$ $2^{1}$ E. NIMET,(2013).

Station 2 (Oversea quarters): This River runs along the main source across settlements. It is used for domestic purposes and block molding with station coordinates at latitude $8^{0} 49^{1} \mathrm{~N}$ and longitude $7^{0} 3^{1} \mathrm{E}$.

Station 3 (Bonugo): This site is equally surrounded by houses; farming activities, washing and block molding as the major activities. Evacuation of soil also takes place as they dig out the soil for building construction. Station coordinates are: Latitude $8^{0} 49^{1}$ $\mathrm{N}$ and longitude $7^{0} 1^{1} \mathrm{E}$.

Station 4 (Koroko): This River is surrounded sparsely by houses; irrigation farming is majorly practiced. Excavation of the top soil also takes place for building constructions. Station coordinates are: Latitude $8^{0} 49^{1}$ $\mathrm{N}$ and longitude $7^{0} 2^{1} \mathrm{E}$. 


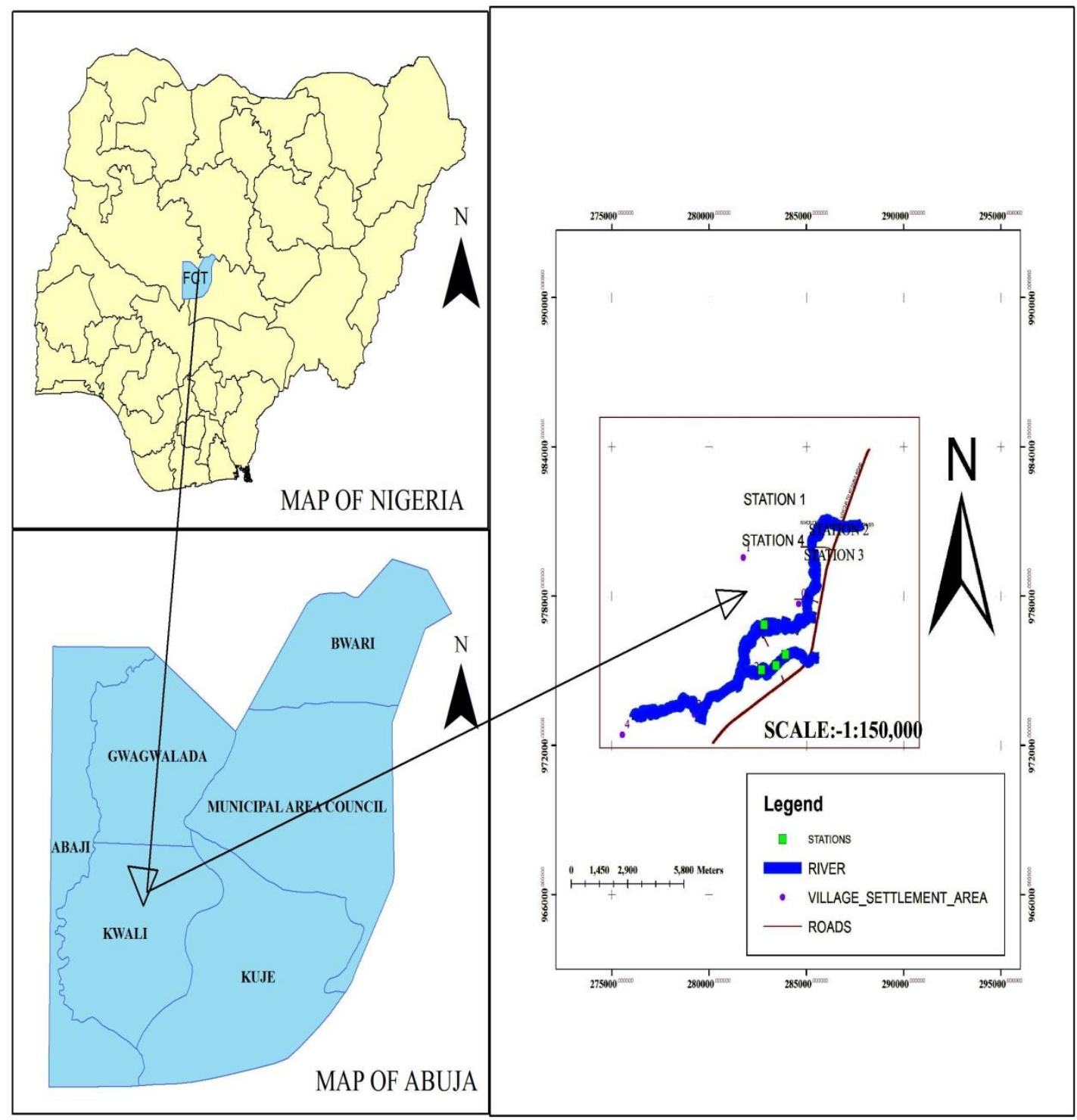

SOURCE: ADMINISTRATIVE MAP KWALI AREA COUNCIL (2018)

Figure 1.Map of Abuja showing the study Area in Kwali.

\section{MATERIALS AND METHODS}

\section{Phytoplankton enumeration}

Samples were collected insitu from the four sampling stations using plankton net of mesh size $50 \mu \mathrm{m}$. The collection was done using a scoop net trawled horizontally in the river. The water sample was concentrated to $100 \mathrm{ml}$ level into phytoplankton bottle, $1 \mathrm{ml}$ of Lugol solution was added and allowed to sediment for 24 hours. $91 \mathrm{ml}$ of the water sample decanted and left with $10 \mathrm{ml}$ of the sample used for species count, ( Prescott, 1982).

Drop count method was used. One $\mathrm{ml}$ of the sample was dropped on the slide covered with a cover slip and mounted on the Olympus Biological Microscope to view and number of cells counted. Prescott (1982) identification method was used.

\section{Statistical analysis}

Descriptive analysis of bar charts was used to determine the percentage abundance of Phytoplankton 
species in the Bodna River. Analysis of data was based on monthly data collection by identification and counting. Analysis of variance (ANOVA) was used to analyse the data using SPSS (2015) version 26 statistical package of $95 \%$ confidence level.

\section{RESULTS}

\section{Distribution and Abundance of Phytoplankton in Bodna River}

The distribution and abundance of phytoplankton in Bodna River were presented in Table 1 and percentage distribution in Figure 2. There were 117379 phytoplankton species encountered in the Bodna River during the study period. There are four major families with 14 species found in the Bodna River which include Chlorophyceae represented by Chlorella ellipsodea, Closterium species, Spirogyra species, Hormidium species, and Ulothrix species. Bacillariophyceae had the following species, Melosira granulata, Fragillaria species, Nitzchria species Diatomella species Tabellaria species and Synedra species. Cyanophyceae had Aphanocarpsa species and Oscillatoria species while the forth group was Euglenophyceae represented by Phacus species. The phytoplankton with the highest abundance was Chlorella ellipsodea with values 26,556 followed by Closterium species with 19,956 then Nitzchria species with 13,364 and the least was Synedra species with
1,970 . The highest percentage was equally observed in Chlorella ellipsodea with $22.6 \%$ followed by Closterium species with $17.0 \%$ then Nitzchria species with $11.4 \%$ and least was Synedra species with $1.7 \%$ (Figure 2).

However, it was observed that there were variations in the availability and number of some species in the sampling stations of the river. The mean distribution of phytoplankton according to the stations is shown in Table 2. In station I, Chlorella ellipsodea was observed to have the highest values 13,050 followed by Closterium species with 8,250 then Nitzchria species with 7,770 and the least was Ulothrix with 217 and Oscillatoria species with 217 (Table 2). Station II was rich in Chlorella ellipsodea with 4460 followed by Melosira granulata with 3617 and the least was Fragillaria species with 40. In sampling station III, Spirogyra species was observed to be the highest with 3,698 followed by Closterium species with 2,114 and the least was Hormidium species with10. Similarly, station IV had the highest Chlorella ellipsodea with 9,046 followed by Closterium with 7,788 and the least was Ulothrix species with 800 (Table 2).

However, some species were not found in some study stations and these had no percentage values. The variations in the seasonal distribution of Phytoplankton as observed in this study indicated highest percentage of phytoplankton with $66.3 \%$ in the wet season and $33.7 \%$ in the dry season as shown in Table 3. 
International Journal of Engineering Applied Sciences and Technology, 2020

Vol. 5, Issue 6, ISSN No. 2455-2143, Pages 128-137

Published Online October 2020 in IJEAST (http://www.ijeast.com)

Table 1: Relative Abundance of Phytoplankton in Bodna River 2018 to 2019

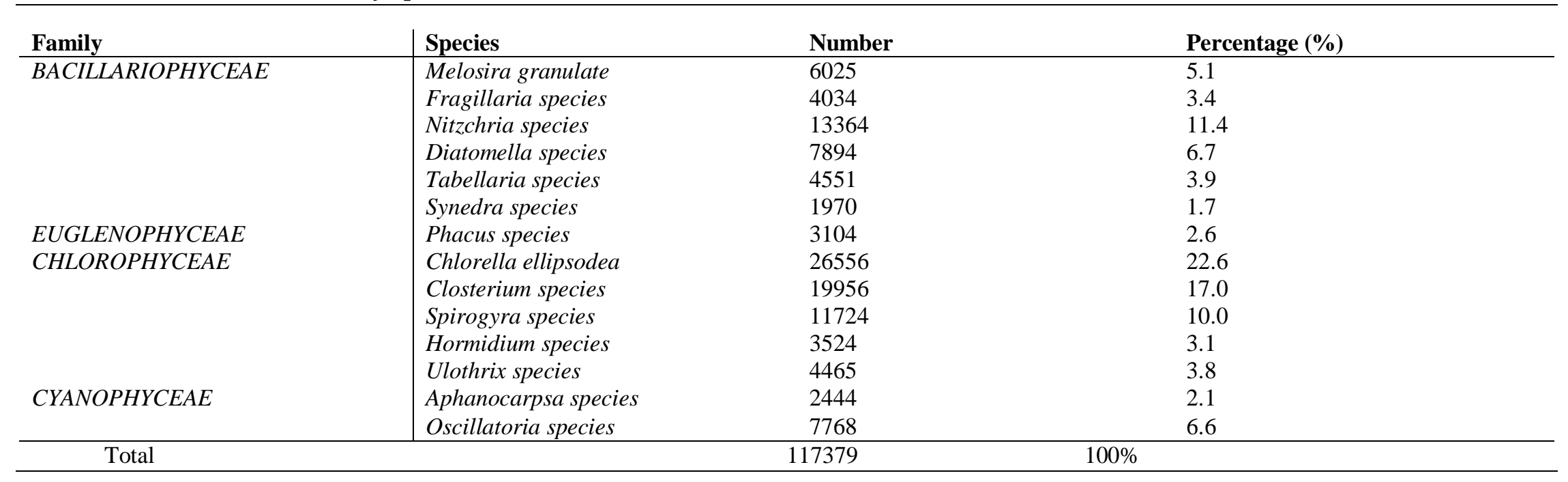

Note: \% means percentage

percentage 
International Journal of Engineering Applied Sciences and Technology, 2020

Vol. 5, Issue 6, ISSN No. 2455-2143, Pages 128-137

Published Online October 2020 in IJEAST (http://www.ijeast.com)

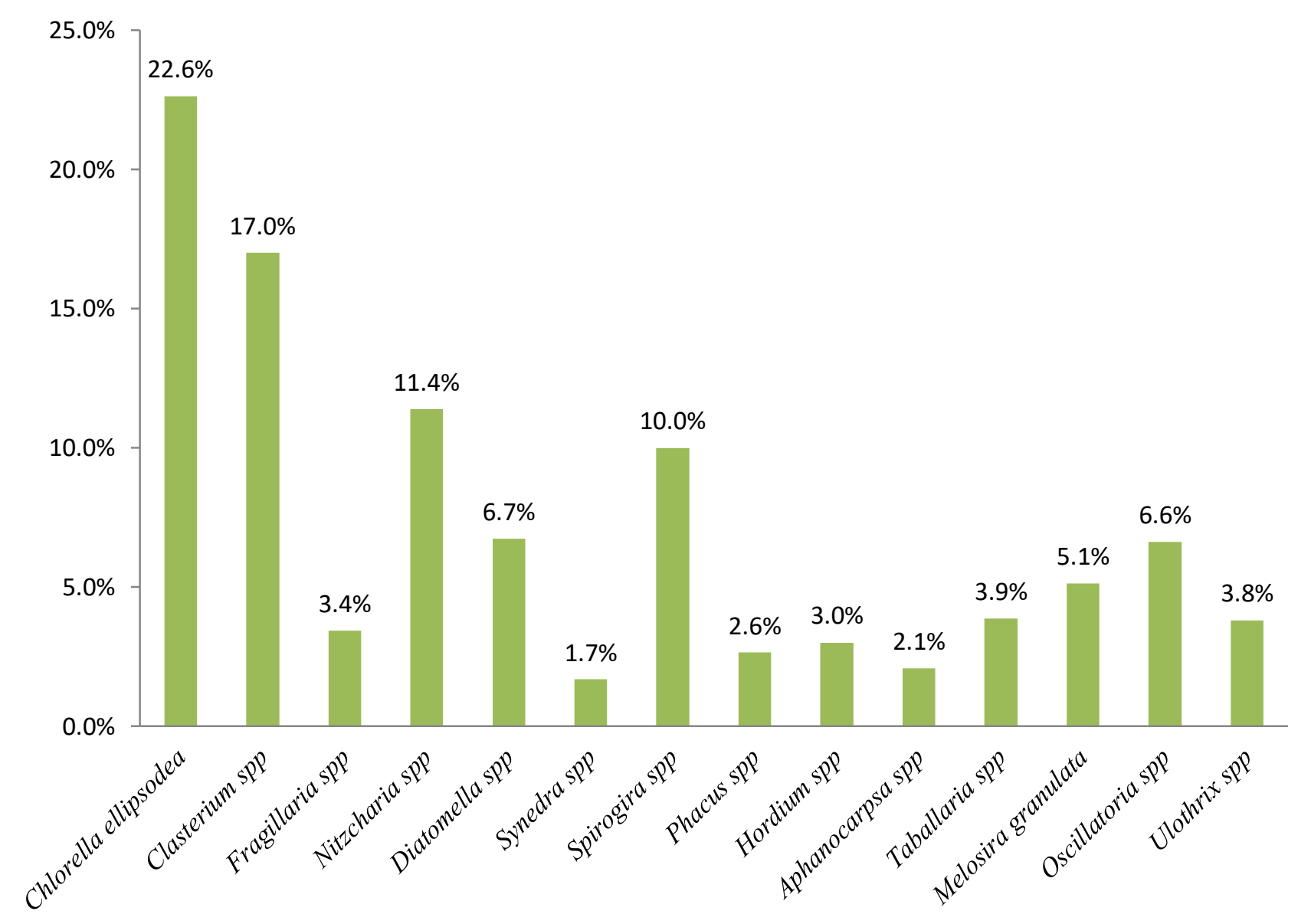

Figure 2: The percentage distribution of Phytoplankton abundance in Bodna River

Table 2: Mean Distribution of Phytoplankton of Bodna River in 2018 to 2019 According to Stations

\begin{tabular}{|c|c|c|c|c|c|c|c|c|}
\hline \multirow{2}{*}{$\begin{array}{l}\text { Species } \\
\text { Phytoplankton }\end{array}$} & \multicolumn{8}{|c|}{ Stations } \\
\hline & $\begin{array}{l} \\
\text { No. }\end{array}$ & Percentage \% & $\begin{array}{l}\text { II } \\
\text { No. }\end{array}$ & Percentage \% & $\begin{array}{l}\text { III } \\
\text { No. }\end{array}$ & Percentage \% & $\begin{array}{l}\text { TV } \\
\text { No. }\end{array}$ & Percentage $\%$ \\
\hline
\end{tabular}


International Journal of Engineering Applied Sciences and Technology, 2020

Vol. 5, Issue 6, ISSN No. 2455-2143, Pages 128-137

Published Online October 2020 in IJEAST (http://www.ijeast.com)

\begin{tabular}{|c|c|c|c|c|c|c|c|c|}
\hline $\begin{array}{l}\text { Melosira } \\
\text { granulate }\end{array}$ & 417 & 1.01 & 3617 & 17.24 & 1991 & 14.60 & - & - \\
\hline $\begin{array}{l}\text { Fragillaria } \\
\text { species }\end{array}$ & 2010 & 4.85 & 40 & 0.20 & - & - & 1984 & 4.80 \\
\hline Nitzchria species & 7770 & 18.76 & 860 & 4.19 & - & - & 4734 & 11.46 \\
\hline $\begin{array}{l}\text { Diatomella } \\
\text { species }\end{array}$ & 2480 & 5.98 & 90 & 0.43 & 550 & 14.03 & 4774 & 11.56 \\
\hline $\begin{array}{l}\text { Tabellaria } \\
\text { species }\end{array}$ & 260.00 & 0.63 & 2490 & 11.87 & 1801 & 13.20 & - & - \\
\hline Synedra species & 1770 & 4.27 & - & - & 200 & 1.41 & - & - \\
\hline Phacus species & 990 & 2.39 & 2114 & 10.08 & - & - & - & - \\
\hline $\begin{array}{l}\text { Chlorella } \\
\text { ellipsodea }\end{array}$ & 13050 & 31.48 & 4460 & 22.00 & - & - & 9046 & 21.90 \\
\hline $\begin{array}{l}\text { Closterium } \\
\text { species }\end{array}$ & 8250 & 19.90 & 1804 & 8.60 & 2114 & 15.50 & 7788 & 18.85 \\
\hline $\begin{array}{l}\text { Spirogyra } \\
\text { species }\end{array}$ & 1630 & 3.93 & 1834 & 8.74 & 3698 & 27.11 & 4562 & 11.04 \\
\hline $\begin{array}{l}\text { Hormidium } \\
\text { species }\end{array}$ & 1730 & 4.17 & - & - & 10 & 0.07 & 1784 & 4.32 \\
\hline Ulothrix species & 217.00 & 0.52 & 1844 & 8.79 & 1604 & 11.76 & 800 & 1.94 \\
\hline $\begin{array}{l}\text { Aphanocarpsa } \\
\text { species }\end{array}$ & 660 & 1.59 & - & - & - & - & 1784 & 4.32 \\
\hline $\begin{array}{l}\text { Oscillatoria } \\
\text { species }\end{array}$ & 217.00 & 0.52 & 1827 & 8.71 & 1674 & 12.27 & 4050 & 9.80 \\
\hline Total & 41451 & $00 \%$ & 20980 & $100 \%$ & 13642 & 100 & 41306 & $100 \%$ \\
\hline
\end{tabular}

Note: Stations with (-) means absence of specie 
International Journal of Engineering Applied Sciences and Technology, 2020

Vol. 5, Issue 6, ISSN No. 2455-2143, Pages 128-137

Published Online October 2020 in IJEAST (http://www.ijeast.com)

Table 3: Mean Seasonal Variation of Phytoplankton Distribution in Bodna River 2019

\begin{tabular}{|c|c|c|c|c|}
\hline Species & & asons & & \\
\hline Phytoplankton & Wet & & Dry & \\
\hline & No. & Percentage \% & No. & Percentage $\%$ \\
\hline Melosira granulate & 4004 & 5.1 & 2021 & 5.1 \\
\hline Fragillaria species & 2421 & 3.1 & 1607 & 4.1 \\
\hline Nitzchria species & 8992 & 11.6 & 4372 & 11.1 \\
\hline Diatomella species & 587 & 6.8 & 2607 & 6.6 \\
\hline Tabellaria species & 2764 & 3.5 & 1787 & 4.5 \\
\hline Synedra species & 1280 & 1.6 & 690 & 1.7 \\
\hline Phacus species & 11627 & 2.1 & 1477 & 3.7 \\
\hline Chlorella ellipsodea & 19263 & 24.7 & 7293 & 18.4 \\
\hline Closterium species & 12919 & 16.5 & 7037 & 17.7 \\
\hline Spirogyra species & 7722 & 9.9 & 4002 & 10.1 \\
\hline Hormidium species & 2212 & 2.8 & 1312 & 3.3 \\
\hline Ulothrix species & 2914 & 3.7 & 1551 & 3.9 \\
\hline Aphanocarpsa species & 1647 & 2.1 & 797 & 2.0 \\
\hline Oscillatoria species & 4777 & 6.1 & 2991 & 7.6 \\
\hline Total & 77835 & $100 \%$ & 39544 & $100 \%$ \\
\hline
\end{tabular}

Note: Highest percentage of phytoplankton was found in the Wet season at $66.3 \%$ and the lowest percentage in the dry at $33.7 \%$ 


\section{International Journal of Engineering Applied Sciences and Technology, 2020 Vol. 5, Issue 6, ISSN No. 2455-2143, Pages 128-137 \\ Published Online October 2020 in IJEAST (http://www.ijeast.com)}

\section{DISCUSSION}

\section{Phytoplankton}

There was a rich population of phytoplankton in the Bodna River represented by four families with 14 species. The families include, Chlorophyceae, Bacillariophyceae, Cyanophyceae and Euglenophyceae which gave the total abundance of species at 117379 during the study with the Chlorophyceae having the highest abundance. This is similar to the study conducted by Idowu et al, (2018), which showed a representative of six families with 33 species, Abdullahi, (2005) and Abubakar (2009) who worked on Hadejia Nguru wetlands which was dominated by Chlorophyta, Lyanophyta, Bacillariophyta and Dinophyta.

The composition of phytoplankton in Bodna River is an indication that the River is not polluted. This also corresponds with the finding of Venvuren et al, (2007) in Mohale Dam in South Africa but differs from the work of Abubakar (2009) on Aspects of Ecology and Fisheries of Nguru Lake indicated that the family Cyanophyceae was more dominant in most sites which caused deterioration of water quality. The phytoplankton of Bodna River undergoes seasonal changes in both composition and relative abundance. There was a decline in the population during the dry season between November and March. This may be attributed to fluctuations in the physical, chemical and biological characteristics of the River. This finding disagrees with the work of Abubakar (2009,2015) with phytoplankton declining during rainy season at Nguru lake. Similarly, the relationship between phytoplankton and physical and chemical parameters was positive which contradicts Abubakar $(2009,2015)$ that reveals negative relationship.

\section{CONCLUSION}

The distribution and abundance of phytoplankton in the four sampling stations belongs to major group of the families; Chlorophyceae, Bacillariophyceae, Cyanophyceae and Euglenophyceae. However, it was observed that there are variations in the ability and number of some species in the sampling stations and the family Chlorophyceae was highest in abundance. The zooplankton community in the river were represented by three main groups which includes; Rotifera, Cladocera and Copepoda. There was species variation within the sampling stations and from season to season while the highest abundance was observed in the wet season with Rotiferans as the highest.

\section{RECOMMENDATION}

Area of further studies should focus on some specific useful phytoplankton and zooplankton in the river as live food for the fish species to enhance management and sustainability of fishing resources in Kwali Area Council.

\section{REFERENCES}

1 Abdullahi, A.Y.,(2005). A Biological Survey of the Kangimi Reservoir, Kaduna State, Nigeria, ( pp. 43).

2 Abowei, J.F.N. (2010). Salinity, Dissolved oxygen, $\mathrm{pH}$ and Surface water temperature conditions in Nkoro River, Niger Delta, Nigeria. Advanced Journal of Environmental and Earth Science, 1 (2): ( pp.145-532).

3 Abubakar, M.M. and Auta, J. (2015). Biodiversity of abundance of fish and macrobenthic invertebrates of Nguru Northeasthern Nigeria. Journal of Aquatic Sciences.24(1): (pp.25-29).

4 Abubakar, M.M. (2009). Effect of pollution on phytoplankton Distribution in Salanta and Challawa rivers, kano Nigeria, (pp.23-30).

5 Anago, I.J., Esenowo I.K. and Ugwumba, A.A.A., (2013). The physico-chemical and plankton diversity of Awba Reservoir, University of Ibadan, Nigerian Research Journal of Environmental and Earth Sciences, 5 (11): (pp.638-644).

6 Barlow, R., Louw, D., Balarin,M. and Alheit, J. (2006). Pigment signatures of phytoplankton composition in the Northern Benguela ecosystem during spring. African Journal of Marine Science.28(3\&4): (pp.479-491).

7 Boyd, P.W., Wong R. and Lee, H. (2000): A Meso scale phytoplankton bloom in the polar southern ocean stimulated by iron fertilization nature 407: (pp.695-702).

8 Brooks, J. L., and Dodson, S. I. (1995). Predation body size and composition. Plankton science, 150: (pp.28 - 35).

9 Crul, R.C.M. (1993). Monographs of the East African great Lakes. Limnology and hydrology of Lake Victoria. Part 1. United Nations Educational Scientific and Culturs Organization, UNESCO project M- S.1 Comprehensive study of great Lake, (pp. 68).

10 Dankishiya, A.S., Olatunji, A.A., and Balogun, J.K. (2013). Ichyofauna composition and diversity of a tropical water supply reservoir in Bwari, Abuja, Nigeria. American Journal of Research Communication.15: (pp.365-377). 
11 Efe, S.T. (2000). An Appraisal of the Quality of Rain and Groundwater Resources in Nigerian Cities. The case of Warri Metropolis. A. Ph.D seminar paper presented to the Department of Geography and Regional Planning, Delta State University, Abraka, (pp. 29).

12 Farah, N., Zia MA, Rehman K, and Sheikh, M. (2002). Quality characteristics and treatment of drinking water of Faisalabad city. International Journal of Agricultural Biology3: (pp.347-349).

13 Idowu E.O., Ugwumba A.A.A., Edward J.B and Oso J.A. (2013). Study of the Seasonal Variation in the Physico-Chemical Parameters of a Tropical Reservoir. Greener Journal of Physical Sciences, 3 (4): (pp.142-148).

14 Idowu R.T., Ali F.A., Mathew O. and Ahmed A.(2018). Dynamics of Phytoplankton Assemblages in Lake Chad Nigeria. Elixir Agriculture,121: (pp.51535-51541)

15 Lovik, J.E. and Kijellberg, G., (2003). long term changes of the crustacean zooplankton community in lake Ngosa the largest lake in Norway, limnology.62: (pp.143150).

16 Mizuno, T. (1990). Illustration of freshwater plankton of Japan. Hoikush publishing co.Japan.

17 Nigerian Meteorological Agency, NIMET (2013). Application of meteorological information in weather disaster risk reduction and socio-economic planning. Conference held on the 12-14 February, 2013 at Ladi Kwali Hall, Abuja.

18 Oboh, I.P. and Agbala,C.S. (2017). Water quality assessment of the Siluko River,Southern Nigeria. African Journal of Aquatic Science, DOI: $10.2989 / 16085914.2017 .1371579$

19 Ovie, S. I. (2011): A synopsis of the zooplankton fauna of Lakes Kainji and Jebba. In: Forty years on Lake Kainji fisheries research. Eds: Raji, A. Okaeme, A. N. and Ibeun, M. O. published by National Institute for Freshwater Fisheries Research, NIFFR, NewBussa, Nigeria. 1: (pp133-143).

20 Pannard, A.M., Bormans and Lagadeue, Y. (2007): short term variability in physical forcing in temperate reservoir effects on phytoplankton dynamics and sedimentary fluxes.Freshwater Biology 52(1): (pp.12).

21 Prescott, G.W. (1982). How to know freshwater Algae. 3rd edition. The Pictured key nature series. WM. C. Brown company publisher. Dubuquete lowa. University of Montana, (pp.75-250).

22 Scondergaard, M., Williams, P.J., Cauwet, G., Riemann, B., Robinson, C., Terzic, S.,
Woodward, E.M.S. and Worm, J. (2000). Net accumulation and flux of dissolved organic nitrogen in marine plankton communities. Limnology and Oceanography,45: (pp.10971111).

23 Vanvueren, D.P., Lucas, PL. and Hilderink, H. (2007). Downscaling drivers of global environmental changes. Enabling Global SRES scenarios at the natural and grid levels. Article google scholar. Global environmental change.17: (pp.114-130).

24 Wetzel, R.G. (1983). Limnology 2nd edition, saunders college publishing, Philadelphia,(pp.860). 